\title{
On The Retranslation of the Igbo Missal
}

\author{
Chidoo Ezika \\ Department of Linguistics, Igbo \& Other Nigerian Languages, University of Nigeria, Nsukka, Nigeria
}

\begin{abstract}
This study looks at the translation and the retranslation of the Igbo missal in line with New mark's (2001) semantic and communicative theory of translation. The aim is to highlight the factors that necessitated the retranslation, looking at the loopholes of the first translation in comparison with the Latin and English source texts. This study adopts the Newmark's translation theory which sees translation from language and equivalence perspectives. The data were gathered from both old and new Igbo missals, the Latin missal and from the old English missal. Some persons were also interviewed to see the level of acceptability of the new translation. The study finds out that the first translation of the missal, hinges on communicative translation which focuses on the target language users. The retranslated version, hinges on the semantic translation which focuses on the source text language as requested by the Church authority. The study shows that many have accepted the translation while few are of the opinion that the new translation is not suitable. The paper concludes that the retranslated version is faithful to the source text and that the dangers of loss of meaning and possible incomprehensibility are not visible.
\end{abstract}

Index Terms - translation, retranslation, Igbo Missal, communicative translation, semantic translation

\section{INTRODUCTION}

Language remains a vital tool for human communication and integration. It is of such importance that it, like an animate object, is being nurtured and it also responds to 'stimulus'. Therefore, it is sensitive to man's positive or negative activities towards it (See Batido, 2005; Skutnabb-Kangas, 2018). Consequently, there is the need to have a positive attitude towards any language to ensure its viability. One of the ways of promoting a language is its usage in every activity of the users and being able to study it at any level of academics, what Kaschula \& Nkomo (2019) refer to as language intellectualisation. In religion, language is very essential. In the Christian and African traditional religions, language plays a key role. Through it, communication takes place - the vertical (divine) and horizontal (human) patterns of participation (Davidson, 1992).

In the Catholic Church, the Masses were before the Second Vatican council (Henceforth Vatican II) said in Latin. The Latin language before then was seen as a sacred language (lingua sacra) (Liddicoat, 1993). The Church fathers during the Vatican II affirms that celebrating the Mass and other activities using the vernacular is beneficial to the people (Vatican II). The usage of vernacular was debated and approved during the Vatican II. The usage as O'Collins \& Wilkins (2017) note began before Vatican II in some areas in Europe but it was, of course, not official. On approving the use of vernacular, there is the need to translate the Missal into various languages of the world with a final approval from Rome; what Oyali (2017) sees as a reflection of power relation.

The barriers in any communication exercise defeat the intention of the giver of the information towards the receiver. This was what triggered the Catholic Church to allow the usage of vernaculars in liturgical celebrations globally in 1964. Liddicoat (1993) notes that Pope Paul V as far back as 1615 allowed the clerics in China to say Masses in vernacular using the Chinese Missal. As beautiful as this gesture is, it was resisted from many quarters. The intentions of the critics were not out of hatred for the Church authority and their decisions. It was their 'love' for the Church and 'fight' against the seeming 'watering down' of the Church (Chupungco, 2010; Maye, 2015 \& Harris, 2017). The Church authorities, however, maintained their position which was born out of the quest for active participation of the people during liturgical celebration (Congregation for divine worship and the discipline of the sacraments, 1964). Before the adoption of the vernacular, Gy (2003) notes that it was a case of "thinking as a community, where the majority in the community truly listens to the minority and resists the temptation to polarization" (p.13). The prayer of the faithful was the only section of the Mass said with the vernacular. Thus, in 1964, the Vatican II ended. The Church authority produced a document known as Comme le prévoit "for those who are called to prepare, to approve, or to confirm liturgical translations" (Comme le prévoit, 1969, p.1). The official use of vernacular in liturgy globally as Gy (2003) records was on the first Sunday of Lent, 1964.

The first Igbo Missal produced by Catholic Bishops of the Igbo speaking areas came into existence in 1973. It was translated following the guideline stipulated in Comme le prévoit. In 2018, under the guidance of Liturgiam authenticam, the second was published. Scholars like Storsor (2018) and Muonwe (2019) see the 1963 Comme le prévoit and the 2011 Liturgiam authenticam as the major guides for the translatorial teams. It is on this premise that this study connects both of them to the translation principles of Newmark- communicative and semantic translation. Due to the dearth of works on the retranslation of the Igbo missal, this study is a continuity of Muonwe (2019) who studied the concepts of тmиo (spirit) and umunne (brothers and sisters) with regards to the Igbo worldview and liturgy in the new translation. This study seeks to provide the answers to the reason why the Catholic Church in Igbo speaking areas had to 
embark on retranslation. It highlights some of the core differences between the two translations. This was done by looking at the structure and syntax of the two Igbo translations in relation to the old English missals which was partly, as observed, the source texts of the old Igbo missal and the Latin text which was solely, the source text of the new Igbo translation.

\section{THE CONCEPT OF RETRANSLATION}

A translation, most times is time bound. Its acceptance changes with time due to certain societal and linguistic factors. When it is no longer acceptable due to its perceived incompleteness and unsuitability to the audience it is meant for at a particular time, a retranslation is done to maintain the information link and/or improve on the language (See SusamSarajeva, 2003; Oyali, 2018 \& Ezika, 2020). The unsuitability of a translation may be linguistic or cultural because language and culture evolve. Retranslation is as an act of translating again, what has earlier been translated into the same language by the same or other translator(s). Sometimes, the aim is to improve or correct the earlier translation. Tahir Gürçağlar (2009) and Koskinen \& Paloposki (2010) refer to it as a process and also as a product. It can also be seen as an attempt for a retranslator, in the case of literary translation or other translations like the religious translation which have the attributes of literary translation (Delabastita,2011) to change the translation style -sense for sense or word for word (domestication and foreignisation) for instance. Cadera \& Walsh (2017, p.1) present a summary that,

each new translation must represent a socio-historical change and that, although the decision to retranslate a work may undoubtedly be due to acommercial decision on the part of the publisher, it must also be linked to external changes in the historical, cultural and social context of the targetculture or to changes in the poetic and aesthetic considerations of the translations themselves.

From another perspective, it could be an aim to thwart communication for political reasons (See Tymoczko \& Gentzler, 2002; Rubel \& Rossman, 2003). Since information can be hidden in the process of translation, such can also take place in retranslation. This connects to the concept of institutional translation where an institution determines what the translator does. A process that appears to place the translator on the level of a slave or a traitor. Oyali (2018) while discussing the translation of the different Bible versions into the Igbo language, noted that the Igbo Bibles for the Catholics, Jehovah's Witness and the Protestants were done "for ideological reasons" (p.98). The translation and the retranslation of the Missal, like the Bible, is determined by the institution and in this case, the Catholic Church (See Venuti, 2013). Mossop (2014) notes that "the institution does not act on behalf of an entire culture; rather it serves specific groups by producing translation that address specific readerships" (p.3). Koskinem (2014) in affirmation reveals that language use in institutions is controlled and translation is not owned by an individual.

The notion of retranslation hypothesis of Berman (1990) which was inspired by Von Goethe's (1992) claims that the subsequent translations are better than the first translation. For Berman, a translation is an "incomplete act that can only strive for completion through retranslation" (Berman, 1990, p.1). This hypothesis, however, is not generally applicable in translation and therefore, not enough to explicate retranslation (See Koskinen \& Palopski, 2010). They (Koskinen \& Palopski, 2010) argue that, though there are cases where the first translations are not close to the original and the subsequent translations are, there are also cases where it is the other way round. It is important to note that the retranslation hypothesis did not capture the retranslation route. That is, what Pym (1998) refers to as passive and active types of retranslation. Passive retranslation occurs when the retranslator is not aware of an initial translation while in active retranslation, there is a clear disagreement between the initial retranslation over the translation strategies applied. It is in attempting to arrive at a better strategy in the subsequent retranslation that the closeness to the source becomes possible. As it concerns the retranslation of the Missal, the Liturgiam authenticam disagrees with the Comme le prévoit.

\section{NEWMARK'S TRANSLATION THEORIES}

Newmark's (2001) communicative and semantic translation theories are one of the linguistic theories of translation. The double-edged component makes it appropriate in accommodating the two translation paths mostly seen in literary translations and other texts that share the same characteristics with it such as religious texts (Delabastita, 2011). The literary translation paths of foreignisation and domestication where the translator either follows the author or goes with the reader (See Venuti, 2012) are closely related to semantic translation and communicative translation. Newmark's (1988 \& 2001) aim was to replace Nida's dynamic and formal equivalence which he argued against because of his (Nida's) perception of full equivalence. Nida (2000) notes that a "translation of dynamic equivalence aims at complete naturalness of expression, and tries to relate the receptor to modes of behaviour relevant within the context of his own culture" (p.129). Not comfortable with the 'complete naturalness of expression', Newmark came up with communicative translation which "is intended primarily to achieve a certain effect on its reader's mind, which effect could only be verified by a survey of their mental and or physical reactions" (Newmark, 2001, p.42). Communicative translation, as Newmark (2001, p.39) states;

attempts to produce on its readers an effect as close as possible to that obtained on the readers of the original... it addresses itself solely to the second reader, who does not anticipate difficulties or obscurities, and would expect a generous transfer of foreign elements into his own culture as well as his language where necessary. 
As its name indicates, communicative translation simply communicates. It passes the content of the source text to the reader of the translation in his own language and worldview with the central message of the original information intact. The reader therefore, because of the familiarity of the expressions feels at home.

On the other hand, semantic translation "attempts to render, as closely as the semantic and syntactic structures of the second language allow, the contextual meaning of the original" (Newmark,2001, p.39). It is as Newmark (1996) posits, "author centred; semantic and syntactic oriented. Length of sentences, position and integrity of clauses, words position, etc. preserved where possible" (p.11). Munday (2016) observes that it is accurate in the communication of the source text message in the target text. Semantic translation, unlike communicative translation has no room for the translator to improve on logic in the source text or replace clumsy expressions. It brings the text closer to the "formal elements of the original, including where possible, its sound effect" (Newmark, 2001, p.44). For Newmark, "all translations must be in some degree both communicative and semantic" (Newmark, 2001, p. 62). However, the degree of emphasis shows where the translator's loyalty lies. In semantic translation, while the translator's loyalty is to the author, in communicative translation, the translator is loyal to the source text language norms.

\section{PREVIOUS STUDIES}

Muonwe (2019) in his study analysed two changes that occurred in the new Igbo translation. They are the translations of Et cum spiritu tuo and Fratres. Their translation in the new Igbo Missal - Nonyekwara mmuo gi and Umunne as against Nonyekwara gi and Umunna are built not just on the surface structure, but also on the Igbo world view. The old Igbo Missal omitted the mmuo just like that of the English which omitted 'spirit'. This could be as earlier mentioned, the usage of the old English Missal as a source text or the misconception of mmuo by the translators as Muonwe (2019) reveals. St John Chrystoton as Stravinskas (2010) reveals, teaches that when the people respond '... with your spirit', they recognise the sacramental transformation of the priest at ordination to enable him transform the bread and wine into the body and blood of Christ. Aside this theological view, the English language and the Latin language are placed high in Nigeria and in the Catholic Church respectively. As such, English Masses are often said in many parts of Igbo land and the Latin Language is sometimes employed. These two languages have '... and with your spirit' and '...et cum spiritu tuo' respectively. One wonders why it is omitted in the Igbo missal used by people who also use the English and the Latin Missals. This is similar to the deficiencies seen in the translation of liturgical texts of the Efiks as presented by Naseri (2018). The Efik translators of the southern Nigeria because of "fear of confusion and offending the sensitivity of the people" retains English terms like 'spirit' in their local translations (Naseri, 2018, p.73). He punctures the argument and maintains that the insistence in using English terms is simply a neglect to the development of the indigenous language. An opportunity they would have keyed in to expand and multiply their lexicon (See Akwanya, 2014 \& Oyali, 2018). Naseri insists that since the Efik people acknowledge the existence of good and evil spirit. Nothing should have hindered the translation of Holy Spirit as Edisana Ekpo - Holy Spirit.

On the translation of Fratres, a Latin word for 'brothers', the old English translation has 'Brothers and sisters' and the old Igbo Missal has Umunna. Umunna in the Igbo worldview entails the bond between males of a family. It excludes the sisters known as the umuada and even those not under the two umbrellas. Muonwe (2019) argues that the translation of umunna did not reflect the meaning of 'brothers' in the scripture. He further affirms the new translation of umunne which reflects the biblical spirit of communisation. He further notes that nwanne, singular form of umunne, can be used to refer "to any beyond one's family who shows love to someone or who extends hands of fellowship or assistance to someone in time of trouble."

\section{THE RETRANSLATION OF THE IGBO MISSAL}

The first Igbo translation which has the Latin and the English Missals as the source text was ad interim between 1971 to 2017 (46 years) when the second translation came into existence. It, however, was available to the people in 2019. Like in other languages, the Igbo Catholics are not left out in these translation challenges because it came with many changes (See Muonwe, 2019).

The Liturgiam authenticam directs that the names of the translators and their qualifications be stipulated before the final approval from Rome, the new Igbo Missal was translated by the following persons with Bishop Dennis Isizor as the liason Bishop (See Isizor, 2019).

a. Anyanwu, Rev. Fr Gerald (Ph.D. Christian and Classical Literature)

b. Chinagorom, Rev. Fr Longinus (Ph.D in Linguistics/Igbo, M.A. Igbo, B.A Linguistics/Igbo)

c. Ezenduka, Msgr Cyril (Masters in Sacred Music)

d. Ezeomeke, Mr Simon Odili (M.A. Igbo, B.A. Igbo)

e. Madubuko, Msgr Lawrence (Laurea in Sacred Liturgy)

f. Madueke, Msgr Jerome (Laurea in Dogmatic Theology)

g. Ngoesi, Mr. Michael (Masters in Igbo Language)

h. Odajiri, Rev. Fr. Samuel (HND Mass Communication, M.A Education and Administration)

i. Ogudo, Msgr Donatus Emeka (Laurea in Sacred Liturgy)

j. Uba, Rev. Fr. Bartholomew (Masters in Christian and Classical Literature) 
In addition to these qualifications, the priests in the committee have at least a Diploma and/or a working knowledge of the Latin Language. This confirms the assertion that the translation of the Missals, according to Arceño (2010) from the Latin Language is a "reversal of the death of the importance of the Latin language" (p.12-13). This is because, according to him;

Latin has always remained important to the identity of the Church, as official statements, phrases within the Church, the original Missal, and the like are all presented in Latin, before being retranslated. The fact that the English Mass must now be retranslated to keep close to the original Latin form is thus an important focal point in the discussion of where the non-English languages stand. Moreover, the fact that many of the non-English languages were originally translated from the Latin, rather than the English form, suggests there must have indeed been translators proficient in both the non-English languages, as well as Latin, in order to spread the Word at the vernacular level.

Benneth (2018) in affirmation to the above assertion notes that, to say that the Latin language is dead is not right. He preferred that the language is said to be preserved and fixed due to the fact that they are alive in sacred texts.

\section{COMME LE PRÉVOIT VS LITURGIAM AUTHENTICAM}

The Comme le prévoit issued in 1969 guided the teams of translators handling the translation of the Missal into various languages of the world. It adopted the Nida's dynamic equivalence which is similar to Newmark's communication translation (Munday, 2016). This concise document informed the translators of the Missal that a good translation should not be a word for word translation. It further tells them to adopt the nearest in meaning of such words where exact replacements cannot be seen. Comme le prévoit goes on to say in article 6 that the aim of translating a liturgical text "is to proclaim the message of salvation to believers and to express the prayer of the church to the Lord". It notes that;

to achieve this end, it is not sufficient that a liturgical translation merely reproduces the expressions and ideas of the original text. Rather, it must faithfully communicate to a given people, and in their own language, that which the Church by means of this given text originally intended to communicate to another people in another time. A faithful translation, therefore, cannot be judged on the basis of individual words: the total context of this specific act of communication must be kept in mind, as well as the literary form proper to the respective language.

The Comme le prévoit directed the translators, that the unit of meaning is not the word itself but the entire passage. It warns them not to attach any importance to a particular phrase which may weaken the entire meaning.

Interestingly, one of the opposing voices to this translation method, Cardinal Arinze says that the use of the translations does not make the prayers of the Church invalid (Arinze, 2006). He, however, criticised the liberal approach of the translation. He argued that language spoken by many people today have many shades. He noted that there is a difference in English used in a country's Constitution, that spoken by the President, the language of conversation of dock workers or students and that between parents and children. Though all are using English, the expression cannot be the same. He states that the major characteristics of the source text should be maintained in the translations. Using the triple repetition characteristics, like the "mea culpa, mea culpa, mea maxima culpa"; Kyrie eleison"; "Agnus Dei qui tollis... " as examples, the translations, for him, "should neither kill nor flatten out such a characteristic". Arinze's argument aligned with Crystal's (1964), Liddicoat's (1993) and Sawyer's (1999) assertions that a religious language must be a language different from the everyday language which may among others may be a variety of the users' language. On the dual usage of a language, Benneth (2018) talks about the concept of diglossia. A situation where a language has two varieties and are seen as high variety $(\mathrm{H})$ and low variety $(\mathrm{L})$. The $\mathrm{H}$ variety of such a language is used in literature, liturgy and also in formal education while the L variety is used in informal settings like the living room, parks and shops (See also Beards, 1992). From the above argument, Arinze (2006) supports the Comme le prévoit's direction that "after sufficient experiment and passage of time, all translations will need review" and hence, the establishment of Liturgiam authenticam. Pope John Paul II in the year 2000, promulgated that the English Missal be retranslated. As at that time, the young Fr. Ratzinger who among others complained of the poor English translation in 1963 was then a Cardinal and the Prefect of the Congregation for the doctrine of faith. His duty, therefore, was to defend the doctrine of faith. To say that he engineered the retranslation order may not be out of place because he "never forgot" (O'Connor \& Wilkson, 2015, p.6). He had wanted a translation that is very close to the syntax of the original to preserve the antiquity and beauty of the Latin Missal.

The Liturgiam authenticam, following the pattern of Newmark's semantic translation is after the fidelity of the translator towards the source text structure while at the same time, retaining the meaning. It is important to quickly note that semantic translation is different from literal translation. While literal translation does not respect context, semantic translation respects context (Newmark, 2001). Semantic translation "attempts to render, as closely as the semantic and syntactic structures of the second language allow, the contextual meaning of the original" (Newmark,2001, p.39). The above positions are what translators under the guidance of the Liturgiam authenticam are expected to take. Liturgiam authenticam in article 20 , states that;

while it is permissible to arrange the wording, the syntax and the style in such a way as to prepare a flowing vernacular text suitable to the rhythm of popular prayer, the original text, insofar as possible, 
must be translated integrally and in the most exact manner, without omissions or additions in terms of their content, and without paraphrases or glosses.

Where the biblical or the liturgical text retains words of other ancient languages, like - Alleluia and Amen (Aramaic words), the Liturgiam authenticam says that they should be preserved in the vernacular translations. Also, to be retained are the capitalisation "for honorific or otherwise theologically significant reasons". Pope John Paul II (1993) as cited by Arinze (2006) states that "the arduous task of translation must guard the full doctrinal integrity and, according to the genius of each language, the beauty of the original texts".

\section{THE LITURGIAM AUTHENTICAM AND THE IGBO RETRANSLATION}

The Comme le prévoit which earlier guided the translators of liturgical texts and even the recent Liturgiam authenticam provided rooms for retranslation of the whole or part of the Missal if the need arises. The Comme le prévoit empowers the translators to work "from the original, or, at least from the best available text." This confirms that the old English Missal was part of source text for the old Igbo Missal. The Liturgiam authenticam on the other hand, insists that only the source text must be used. The Comme le prévoit which produced the English Missal in 1970 and the first Igbo Missal in 1971 specifically notes in article 39 that before a translation is formally accepted, "sufficient opportunity should be allowed for experiment by selected congregations in different places. An ad interim translation should be properly approved by the liturgical commission of the conference of bishops." Ad interim or ad experimentum translation refers to a translation being used in the meantime and on experiment.

In the present study, eight excerpts of the liturgical translations are selected for analysis. An attention is paid to the structures of the four texts - The Latin Missal, the old English Missal, the old Igbo Missal and the new Igbo Missal.

\section{DATA PRESENTATION AND ANALYSIS}

In the analysis, the selected excerpts in the source texts were translated to see how they were reflected in the old English and Igbo versions. As observed, the Latin and the English texts were the source texts for the old Igbo version. These selected excerpts in the new Igbo translation, following the guideline given by the Liturgiam authenticam were given as seen below.

\begin{tabular}{|c|c|c|c|c|}
\hline & Latin version & Old English version & Old Igbo version & New Igbo version \\
\hline 1. & $\begin{array}{l}\text { Gratia Domini Iesu Christi, et } \\
\text { caritas Dei, et communicatio Santi } \\
\text { Spiritus sit cum omnibus vobis. }\end{array}$ & $\begin{array}{l}\text { The grace of our Lord Jesus } \\
\text { Christ and the love of God, } \\
\text { and the fellowship of the } \\
\text { Holy Spirit be with you all. }\end{array}$ & $\begin{array}{l}\text { Ka ngọzị nke Onyenweanyị } \\
\text { Jesu Kristi, na ịhụnanya nke } \\
\text { Chukwu nna, na ịdịkọ n'otu } \\
\text { nke Mmụọ Nsọ na-enye dịirị } \\
\text { ụnụ niile. }\end{array}$ & $\begin{array}{l}\text { Ka amara } r \\
\text { Onyenweanyị Jesu Kristi, } \\
\text { na na ịhụnanya nke } \\
\text { Chukwu Nna, na } \\
\text { mmekọrịta nke Mmụo Nsọ } \\
\text { dịirị ụnụ niile. }\end{array}$ \\
\hline
\end{tabular}

A look at the table above shows that the Latin terms - Gratia and communicatio were not properly handled with the principle of semantic translation. Gratia - 'Grace' is seen as Ngozi in the old Igbo version but was retranslated in the new version as 'Amara'. On the other hand, communicatio - 'communion' was explicated as ịdịo n'otu which Liturgiam authenticam abhors. Thus, mmekorịta, the direct translation was given in the new translation.

\begin{tabular}{|l|l|l|l|l|}
\hline & Latin version & Old English version & Old Igbo version & New Igbo version \\
\hline 2. & Et cum spiritu tuo & And also with you. & Nonyekwara gị & Dịịkwara mmụọ gị. \\
\hline
\end{tabular}

Spiritu tuo - 'Your spirit', did not reflect in old English and Igbo versions. The new Igbo version has it as mmuo gi so as to be very close to the source text.

\begin{tabular}{|c|c|c|c|c|}
\hline & Latin version & Old English version & Old Igbo version & New Igbo version \\
\hline 3. & $\begin{array}{l}\text { Gloria in excelsis Deo et in terra } \\
\text { pax hominibus bonae voluntatis. } \\
\text { Laudamus te, benedicimus te, } \\
\text { adoramus te... }\end{array}$ & $\begin{array}{l}\text { Glory be to God on high, and } \\
\text { on earth peace to men who are } \\
\text { God's friends. We praise you. } \\
\text { We bless you. We adore you. } \\
\text { We glorify you... }\end{array}$ & $\begin{array}{l}\text { Otito dị̣rị Chineke n’elu } \\
\text { kacha elu; N’ụwa, udo dịrị } \\
\text { ndị mmadụ ndị ihe ha na-asọ } \\
\text { Chukwu. Anyị etoo Gị. Anỵ̣ } \\
\text { ekwupụta orụ ọma Gị. Anỵ̣ } \\
\text { esekpuoro Gị. ... }\end{array}$ & $\begin{array}{l}\text { Otito dịirị Chineke n'elu } \\
\text { kacha elu; N'ụwa, udo dịịị } \\
\text { ndị mmadụ ndị nwere obi } \\
\text { oma. } \\
\text { Anyị ajaa Gị mma, anyị } \\
\text { agọzie Gị, anyị esekpuoro } \\
\text { Gị,... }\end{array}$ \\
\hline
\end{tabular}

The Latin ...pax hominibus bonae voluntatis - ...peace to men of goodwill, has '...peace to men who are God's friends' in the old English version. The old Igbo translation has it as ...ndị ihe ha na-aso Chukwu. The new translation brought out the direct translation for 'goodwill' and therefore has, udo dịini ndị mmadu ndị nwere obi oma. Laudamus te, benedicimus te, adoramus te- 'We praise you, we bless you, we adore you' were respectively captured strictly. 


\begin{tabular}{|c|c|c|c|c|}
\hline & Latin version & Old English version & Old Igbo version & New Igbo version \\
\hline 4. & $\begin{array}{l}\text { ACCIPITE ET BIBITE EX EO } \\
\text { OMNES: HIC EST ENIM CALIX } \\
\text { SANGUINIS MEI, NOVI ET } \\
\text { AETERNI TESTAMENTI, QUI } \\
\text { PRO VOBIS ET PRO MULTIS } \\
\text { EFFUNDETUR IN } \\
\text { REMISSIONEM PECCATORUM. } \\
\text { HOC FACITE IN MEAM } \\
\text { COMMEMORATIONEM. }\end{array}$ & $\begin{array}{l}\text { TAKE THIS, ALL OF YOU, } \\
\text { AND DRINK FROM IT: THIS } \\
\text { IS THE CUP OF MY BLOOD, } \\
\text { THE BLOOD OF THE NEW } \\
\text { AND EVERLASTING } \\
\text { COVENANT. IT WILL BE } \\
\text { SHED FOR YOU AND FOR } \\
\text { ALL MEN SO THAT SINS } \\
\text { MAY BE FORGIVEN. DO } \\
\text { THIS IN MEMORY OF ME. }\end{array}$ & 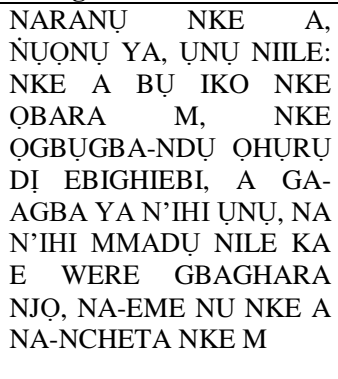 & 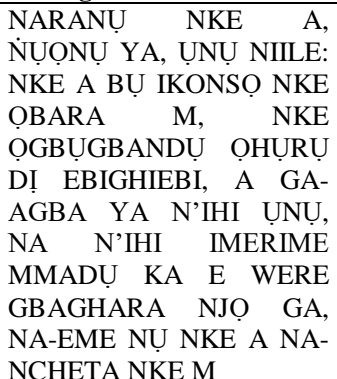 \\
\hline
\end{tabular}

The Liturgiam authenticam advised the translators of the texts to maintain the capitalisation in the source names "for honorific or otherwise theologically significant reason". The Latin Calix - Chalice, a drinking cup used in religious ceremonies was referred to as just a cup and iko (Igbo term for cup) in the old English and Igbo versions respectively. A strict translation of pro multis - 'for many' is seen as n'ihi imerime mmadu in the retranslation. Again, peccatorum 'sins', did not reflect in the old Igbo version in plural form. Isizor (2019) reveals that the Congregation for the Doctrine of Faith noticed that the translators of the new Igbo Missal did not pluralise njo. The attention of the translation committee was called, and it was corrected. Hence, the new Igbo version has ikonso (holy cup) for chalice and njo ga for sins.

\begin{tabular}{|l|l|l|l|l|}
\hline & Latin version & Old English version & Old Igbo version & New Igbo version \\
\hline 5. & Mysterium Fidei: & $\begin{array}{l}\text { Let us proclaim the mystery of } \\
\text { faith: }\end{array}$ & $\begin{array}{l}\text { Ka anyi kwuputanụ ihe } \\
\text { omimi nke okwukwe anyi } \\
\text { na-eme ugbu a: }\end{array}$ & Ihe omimi nke okwukwe \\
\hline
\end{tabular}

The Liturgiam authenticam notes that the Latin Missal has "straightforward, concise and compact manner of expression" and insists that the translators of the Missals into various languages maintain it. The old English and Igbo versions have many additions to the source text information. Instead of 'The Mystery of faith', the old English added an invitation - 'Let us proclaim...'. The Igbo version in addition, added an adverb of time - ugbu $a$ (now). Translating the old Igbo response to English gives - 'Let us proclaim the mystery of faith we are observing now'. The new Igbo version, in maintaining the source text structure, has Ihe omimi nke okwukwe.

\begin{tabular}{|c|c|c|c|c|}
\hline & Latin version & Old English version & Old Igbo version & New Igbo version \\
\hline 6. & $\begin{array}{l}\text { Mortem tuam annunciamus, } \\
\text { Domine, et resurrectionem } \\
\text { confitemur, donec venias. }\end{array}$ & $\begin{array}{l}\text { Christ has died, } \\
\text { Christ is risen, } \\
\text { Christ will come again. }\end{array}$ & $\begin{array}{l}\text { Anyị na-ekwupụta ọnwụ Gị, } \\
\text { na-egosikwa mbilite n'ọnwụ } \\
\text { Gị, O Kristi, wee lue mgbe Ị } \\
\text { ga-abịa ọzọ. }\end{array}$ & $\begin{array}{l}\text { Anyi na-ekwusa ọnwụ Gị, } \\
\text { na-ekwupụtakwa } \\
\text { mbilitenọnwụ Gị, } \\
\begin{array}{l}\text { Dinwenụ, wee ruo mgbe I! } \\
\text { ga-abịa. }\end{array}\end{array}$ \\
\hline
\end{tabular}

The acclamation - Mortem tuam annunciamus, Domine, et resurrectionem confitemur, donec venias - We proclaim your death, O Lord and profess your resurrection until you come again. The Old English translation deviated largely from the source text. It can be referred to what Elliott (2007) sees as "stretching the principle of dynamic equivalence beyond the limits". Ryan (2019) confirms in his paper, Mysterium fidei! The memorial acclamation and its reception in French, English and Polish missals, that the English translation is explicitly very far from the Latin acclamation. The old Igbo expression is closer to the Latin. However, the clauses- Annuntiamus 'We announce/proclaim' and confitemur 'we confess/profess' were not strictly translated. The old Igbo version has 'We announce/proclaim...' and 'we confess/profess...' as Anyi na-ekwuputa... and na-egosikwa... - 'and also show' respectively instead of Anyi naekwusa... and na-ekwuputakwa...

\begin{tabular}{|c|c|c|c|c|}
\hline & Latin version & Old English version & Old Igbo version & New Igbo version \\
\hline 7. & $\begin{array}{l}\text { Praeceptis salutaribus } \\
\text { divina institutione } \\
\text { audemus dicere: }\end{array}$ & $\begin{array}{l}\text { Let us pray with confidence to } \\
\text { the Father in the words our } \\
\text { saviour gave us. }\end{array}$ & $\begin{array}{l}\text { Ụmụnna ka anyị were ekpere } \\
\text { nụ Onye Nzọpụta anỵ̣ kuziri } \\
\text { anyị were kpokuo Chukwu } \\
\text { Nna. }\end{array}$ & $\begin{array}{l}\text { Ebe e nyerela anyị iwu na- } \\
\text { enye ndụ, anyị abưrụkwa } \\
\text { ndị e ji nkuzi nke Chineke } \\
\text { were zụọ, ka anyị were nụ } \\
\text { nkamobi kpee: }\end{array}$ \\
\hline
\end{tabular}

The Latin version has the English translation: 'Prompted by saving precepts, and formed by Divine teachings, we dare to say'. The old Igbo version has a modulated translation of the old English version. Both the old Igbo and English versions did not in any way come close to the Latin. The new Igbo translators provided a good translation in line with the spirit of the Liturgiam authenticam. 


\begin{tabular}{|l|l|l|l|l|}
\hline & Latin version & Old English version & Old Igbo version & New Igbo version \\
\hline 8. & $\begin{array}{l}\text { Domine non sum dignus ut intres } \\
\text { sub tecum meum; sed tantum dic } \\
\text { verbo et sanabitur anima mea. }\end{array}$ & $\begin{array}{l}\text { Lord, I am not worthy to } \\
\text { receive you, but only say a } \\
\text { word and I shall be healed. }\end{array}$ & $\begin{array}{l}\text { Dinwenu, etosighi m ka İ bata } \\
\text { n'ullo m, ma kwuo sọ okwu, } \\
\text { na mkpurụ obi m ga-adịịịị. }\end{array}$ & $\begin{array}{l}\text { Dinwenu, etosighi } \mathrm{m} \text { ka I } \\
\text { bata n'ụlọ m, ma kwuo sọ } \\
\text { okwu, a ga-agwọ mkpụu } \\
\text { obi m. }\end{array}$ \\
\hline
\end{tabular}

Here, both the old English and the Igbo versions are close to the source text except at their last sentences. The old Igbo version, in translating ... et sanabitur anima mea, has a loose translation - ... na mkpuru obi m ga-adịri - ‘... and my soul shall survive'. Sanabitur (third person singular future passive indicative) in a strict sense is 'shall be healed'. The new Igbo version has a translation that reflected it.

\section{SUMmARY AND CONCLUSIONS}

In translation, the source text and the target text cannot be exactly the same. There are always significant differences either in the form (syntax) or in the content (semantics). The level of the correspondence shows how close the target text is to the original. As Nida (2000) observes, the factors responsible for the difference in translation are (a) the nature of the message to be passed across, (b) the aim (skopos) of the author or the translator and (c) the type of the target text readers. The translators of the old Missal who translated under the principle of Comme le prévoit did not do a bad work. They were simply guided by what the client (The Church) needed at that time - an experiment. The new translation, guided by Liturgiam authenticam is closest to the original in terms of the structure of the source language without hindrance to meaning (Stravinskas, 2010; Nulley, 2015; Muonwe, 2019). The two translations in this study were analysed in line with Newmark's communicative and semantic translation. Newmark (2001)'s translation theory, an amplification of Nida's dynamic and formal equivalence sees a text from two perspectives - the author's perspective and the reader's perspective (See Newmark, 2001 \& Venuti, 2012). While communicative translation corresponds to word for word translation (not strictly literal translation), semantic translation corresponds to sense for sense translation - ancient dichotomies dated back to Cicero and Horace, St Jerome and St Augustine (Jerome, 2012 \& Venuti, 2012). Till today, these translation paths created by these ancient translators remain useful in discussing the translation methods for literary and religious translations. While Comme le prévoit falls within the scope of sense for sense translation, Liturgiam authenticam falls under word for word translation. Stravinskas (2010) and Nulley (2015) maintain that translation under the Comme le prévoit is not a translation but a paraphrase while Liturgiam authenticam is the actual reflection of the original.

Today, majority of the Igbo Catholics have accepted the new Igbo Missal. Some are yet to grasp it fully because they are yet to loosen the attachment to the old missal and or be catechised on why the translation came out the way it is. Longenecker (2016), on the 'headache' caused by the new English translation notes that the translators of the Missal did not inform the people on the principles and the objectives of the translation. It is necessary to note that it is near impossible to have a translation that would be accepted by all speakers of a language (See Toury, 2012 \& Brand, 2015). Brand (2015) further avers that it is a "reality of the last fifty years of experimentation with vernacular liturgical language that viewpoints are many and fractured" (p.139). The new English Missal on its part has many critics which may be connected to the many countries where it is in use unlike the Igbo language which has very few speakers in comparison to the English language (See Goodstein, 2011; O’Connel \& Wilksin, 2015). There are always room for amendment and revisions of translations. It is necessary to note here that Pope Francis has called for a revisit to the English translation (O'Collins \& Wilkins, 2017). The big question is: When the revision is done, will it be accepted by his predecessor? It is therefore, appropriate to have a time frame for each translation to avoid having two translations in a decade. A liturgist, Klein (2019) calls on the Pope and his collaborators to shelve the idea of translating the Missal now for the sake of stability. He analysed a situation where people responded with different responses from the old Missal and the new Missal respectively. One imagines the outcome if the third is produced now. He advised that if the intended retranslation is inevitable, it should be produced towards the end of our generation. By then, the number of those that are used to the first translation must have drastically reduced.

This study analysed eight excerpts from four Missals - The Latin source text, the old English Missal, the old Igbo Missal and the new Igbo Missals. From the observation, the old Igbo Missal had the Latin and the old English Missals as its source text. This is evident due to varying and similar contents of the old Igbo Missal towards the Latin text. Although this may appear to be a minor change, Nuella $(2015$, p.126) notes that it shows the "Church's attention to detail and consistency in making sacred the experience of the faithful in order for them to participate effectively" at Masses. This study did not move into the Igbo language grammar and spellings in the two translations and therefore, recommends that for further research. It also recommends that other Igbo prayers earlier translated, be intralinguistically retranslated to shed off the dominant dialects. It is obvious that most of them are wrongly said and sang because of the unintelligibility created by the dialect.

\section{REFERENCES}

[1] Ajunwa, E. (2014). A textbook of translation: Theory and practice. Nigeria: Enovic Ltd.

[2] Akwanya, A. N. (2014). African languages, translation and expansion of language functions: The case of Igbo. Journal of Tourism and Heritage Studies, 3(1), 1-17. 
[3] Batido, H. M. (2005). Language decline and death in Africa: Causes, consequences and challenges. Clevedon: Multilingual Matters Limited.

[4] Beards, A. (1992). The relevance of a liturgical language. The Downside Review, 110(378), 30-44.

[5] Bennett, B. P. (2018). Sacred languages of the world: An introduction. United Kingdom: John Wiley and Sons Limited.

[6] Berman, A. 1990. La retraduction comme espace de la traduction. Palimpsestes, 4, 1-7.

[7] Brand, C. A. (2015). Very members incorporate: Reflections on the sacral language of divine worship. Antiphon, 19(2), 132154.

[8] Cadera, S. M. \& Walsh, A. S. (2017). Introduction. In S.M Cadera \& A.S Walsh (Eds.), Literary Retranslation in Context, (pp 1-3). Oxford: Peter Lang.

[9] Chupumgo, A. J. (2003). Liturgical inculturation: The future that awaits us. Institute of Liturgical Studies Occasional Papers, 96, 248-260.

[10] Crystal, D. (1964). A liturgical language in a linguistic perspective. New Blackfriars, 46(534), 148-156.

[11] Davidson. J. (1992). Patterns of belief at denominational and congregational levels. Reviews of Religious Research. 13, 197205.

[12] Delabastita, D. (2011). Literary translation. In Y. Gambier \& L. C. Doorllaer (Eds.), Handbook of Translation Studies, (pp. 6978). Amsterdam: John Benjamins.

[13] Elliot, P. J. (June 15, 2007). Liturgical translations: A question of truth. Adoremus. Retrieved August 1 from https://adoremus.org/2007/06/liturgical-translation-a-question-of-truth/

[14] Ezika, C. (2020). Translation theory of justifiability. In B. M. Mbah (Ed.), Theories of Culture and Translation, (pp. 15-126). Nsukka: University of Nigeria Press.

[15] Fyan, F. (2019). Mysterium fidei! The memorial acclamation and its reception in French, English and Polish Missals. Liturgia Sacra, 25(1), 69-98.

[16] Gy, P. (2003). Reception of Vatican II liturgical reforms in the life of the church. Milwaukee: Marquette University Press.

[17] Harris, A. (2017). A Fresh stripping of the altars? Liturgical language and the legacy of the reformation in England, 1964-1984 In K. Cummings, T. Matovina \& R. Orsi (Eds.), Catholics in the Vatican II era: Local histories of a global event (pp. 245-274). Cambridge: Cambridge University Press

[18] Isizor, D. (2019, June 9). Daily pastoral journal. Retrieved June 23, 2019 from https://totusdei.net/daily-pastoral-journal.html

[19] Jerome. (2012). Letter to Pammachius (Trans. Kathleen Davies). In L. Venuti (Ed.) Translation studies reader (3rd edition), (pp. 22-30). New York: Routledge.

[20] Kaschula, R. H. \& Nkomo, D. (2019). Intellectualisation of African languages: Past, present and future. In H.E. Wolff (Ed), African languages in culture and societies, (pp. 601-622). Cambridge: Cambridge University Press.

[21] Koskinen, K. \& Paloposki, O. (2010). Retranslation. In Y. Gambier \& L. Doorslaer, Handbook of translation studies (pp.294298). Amsterdam: John Benjamins Publishing Company.

[22] Koskinen, K. (2014). Translating institutions: An ethnographic study of EU translations. London: Routledge.

[23] Liddicoat, A. (1993). Choosing a liturgical language: The language policy of the Catholic Mass. Australian Review of Applied Linguistics, 16(2), 123-141.

[24] Maye, B. (2015). Mass in the vernacular 50 years old this year. The Irish Times. Retrieved July 19, 2020 from https://www.irishtimes.com/opinion/mass-in-the-vernacular-50-years-old-this-year-1.2166508.

[25] Mossop, B. (2014). Editing and revising for translators (2nd edition). New York: Routledge.

[26] Munday, J. (2016). Introducing translation studies: Theories and applications (4th edition). Oxon: Routledge.

[27] Muonwe, M. (2019). Translation of Liturgical/Religious Texts (Catholic Igbo Missal): Transfer or Betrayal of Meaning in the process of inculturation. Ministerium. A Journal of Contextual Theology, 5, 28-46.

[28] Naseri. C, (2018). Challenges of Bible/liturgical translations in the Efik language group. International Journal of Humanities and Social Sciences. 8(3), 67-82.

[29] Newmark, P. (1988). A textbook of translation. New York: Prentice Hall.

[30] Newmark, P. (2001). Approaches to translation. Oxford: Pergamon Press.

[31] Nida, E. (2000). Principles of correspondence. In L. Venuti (Ed.), The translation studies reader (pp. 126-142). London: Routledge.

[32] Nulley, G. (2015). A critique of the English translations of the Roman Canon with a comparative study of their implications. M.Phil thesis. University of Notre Dame, Australia.

[33] Oyali, U. (2017). Translation as social practice: The case of religious translations between English and Igbo. In U. Oyali (Ed.). Perspectives on translation in Africa (pp. 49-67). Retrieved online on July 20 from https://www.academia.edu/34310299/Bayreuth_African_Studies.

[34] Oyali, U. (2018). Bible translation and language elaboration: The Igbo language experience. Ph.D. thesis, Bayreuth International Graduate School of African Studies.

[35] O'Collins, G. \& Wilkins, J. (2017). Lost in translation: The English language and the Catholic Mass. Minnesota: Liturgical Press.

[36] Pym, A. (2014). Method in translating history. New York: Routledge.

[37] Rubel, P. G. \& Rosman, A. (2003). Translation and anthropology. In P.G. Rubel \& A. Rosman (Eds.), Translating cultures: perspectives on translation and anthropology (pp.1-22). New York: Berg.

[38] Storsor, D. A. (2008). A tale of two translations: Rhetorical style of the post-conciliar English translations of the Mass. Theological studies 79(4), 761-781.

[39] Susam-Sarajeva, S. (2003). Multiple-entry visa to travelling theory. Target, 15(1), 1-36.

[40] Searle, M. (1985). The uses of liturgical language. Liturgy, 4(4), 14-19.

[41] Skutnabb-Kangas, T. (2018). Linguistic diversity, language rights and language ecology. Sustainable Multilingualism, 13, $37-$ 59.

[42] Stravinskas, P. M. J. (2010). Defending the new Roman Missal: A response to Father Michael Ryan. Antiphon, 14(1), 142-146. 
[43] Tahir Gürçağla, S. (2009). Retranslation. In M. Baker \& G. Saldanha (Eds.), Routledge encyclopaedia of translation studies (2nd edition). 233-236. New York: Routledge.

[44] Tymoczko, M. \& Gentzler, E. (2002). Translation and power. Amherst: University of Massachusetts Press.

[45] Venuti, L. (2012). Genealogies of translation theory. In L. Venuti (Ed.), Translation studies reader (3rd edition). (pp. 481-502). New York: Routledge.

[46] Venuti, L. (2013). Translation changes everything: Theory and practice. Oxon: Routledge.

[47] Von Goethe, J. W. (1992). Translation. In R. Schulte \& J. Biguenet (Eds.), Theories of translation: An anthology of essays from Dryden to Derrida (pp. 60-63). Chicago: University of Chicago Press.

Chidoo Ezika hails from Alor, Idemili South L.G.A of Anambra State. He is a lecturer at Department of Linguistics, Igbo and Other Nigerian languages, University of Nigeria, Nsukka. He specialises in translation and interpreting studies. Among his publications is the translation of Charles Dicken's Oliver Twist into the Igbo language and culture. He has also translated for local and international organisations like the Federal Ministry of Health, Nigeria; Chatham House; WHO and Columbia University, USA etc. 